\title{
Assimilation of SeaWiFS chlorophyll data into a 3D-coupled physical-biogeochemical model applied to a freshwater-influenced coastal zone
}

\author{
Clément Fontana ${ }^{\mathrm{a}, *}$, Christian Grenz ${ }^{\mathrm{a}, \mathrm{b}}$, Christel Pinazo $^{\mathrm{a}}$, Patrick Marsaleix ${ }^{\mathrm{c}}$, Frédéric Diaz ${ }^{\mathrm{a}}$ \\ a Laboratoire d'Océanographie Physique et Biogéochimique (UMR 6535), CNRS-Université de la Méditerranée, Station Marine d'Endoume, Chemin Batterie des Lions, \\ F13007 Marseille, France \\ ${ }^{\mathrm{b}}$ Departamento de Hidrobiologia-IRD, Universidad Autonoma Metropolitana, Av. San Rafael Atlixco No 186, Col. Vicentina, Iztapalapa, C.P. 09340, México D.F, Mexico

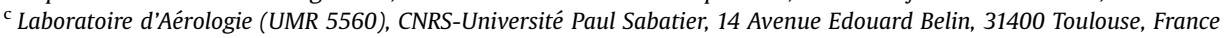

In order to predict eutrophication events in coastal areas we tested an assimilation scheme based on sequential data assimilation of SeaWiFS chlorophyll data into a coupled 3D physical-biogeochemical model. The area investigated is a semi-enclosed estuarine system (Gulf of Fos-North-western Mediterranean Sea) closely linked to the Rhone River delta. This system is subjected to episodic eutrophication caused by certain hydrodynamic conditions and intermittent nutrient inputs. The 3D hydrodynamic model Symphonie was coupled to the biogeochemical modelling platform Eco3M. Surface chlorophyll concentrations were derived from SeaWiFS data using the OC5 algorithm and were sequentially assimilated using a singular evolutive extended Kalman filter. Assimilation efficiency was evaluated through an independent in situ data set collected during a field survey that took place in May 2001 (ModelFos cruise). An original approach was used in constructing the state vector and the observation vector. By assimilating pseudosalinity extracted from the model biogeochemical dynamics in both open sea and plume region were respected. We proved that substantial improvements were made in short-term forecasts by integrating such satellite-estimated chlorophyll maps. We showed that missing freshwater inputs could be corrected to a certain extent by the assimilation process. Simulated concentrations of surface chlorophyll and other basic components of the pelagic ecosystem such as nitrates were improved by assimilating surface chlorophyll maps. Finally we showed the coherent spatial behaviour of the filter over the whole modelled domain.

\section{Introduction}

Eutrophication assessment in coastal waters and estuaries has become a major challenge (McIntyre, 1995; Tett et al., 2007), for instance in Europe where the need to diagnose marine eutrophication has been stated in the EU Water Framework Directive (WFD, 2000/60/EC). Large scale and long term studies of coastal waters to assess eutrophication are logistically difficult using traditional in situ measurement techniques. An alternative is to use remotely sensed observations from satellite images which increase significantly the spatial and temporal coverage of physical and biogeochemical measurements in surface waters. New techniques based on assimilation of these data into

\footnotetext{
* Corresponding author. Tel.: +33491041641; fax: +33491041643.

E-mail addresses: clement.fontana@univmed.fr (C. Fontana),

gren@xanum.uam.mx (C. Grenz), christel.pinazo@univmed.fr (C. Pinazo), patrick.marsaleix@aero.obs-mip.fr (P. Marsaleix),frederic.diaz@univmed.fr (F. Diaz).
}

bio-physical models have recently been developed. Spitz et al. (2001) assimilated data from the Bermuda Atlantic time series (BATS) site into an ecosystem model coupled to a one-dimensional physical model and used the assimilations to guide model improvements. Schartau et al. (2001) assimilated data from BATS into a zero-dimensional model. Friedrichs (2001) assimilated data from the Joint Global Ocean Flux Study (JGOFS), Equatorial Pacific Process Study (EqPac) and satellite data into an ecosystem model. Additional examples of studies related to data assimilation in ecosystem models can be found in Carmillet et al. (2001), in Gregg (2008) and for coastal waters in Huret et al. (2007). Harmon and Challenor (1997) demonstrated the ability of the Monte Carlo Markov Chain method to estimate the parameters of a simple ecosystem model but it has not to our knowledge been tested in an application with real ecosystem data. In coastal waters the challenges when assimilating remotely sensed data are related to the low accuracy of satellite-estimated chlorophyll concentrations and the high non-linearity of coupled models. Recent developments in water reflectance-based algorithms for chlorophyll 
estimation and sub-optimal sequential assimilation schemes represent promising tools for reliable data integration processes in environmental modelling. Different techniques of sequential satellite data assimilation in large-sized models have been more or less successfully applied. Most of these are based on the Kalman theory and were tested in the Cretan Sea (Triantafyllou et al., 2003) and in the Ligurian Sea (Lenartz et al., 2007; Raick et al., 2007). The dimension of the system (order $10^{6}$ ) generally used in 3D modelling does not allow a direct implementation of such methods mainly based on model error covariance matrices. The singular evolutive extended Kalman (SEEK) filter (Pham et al., 1998) overcomes this problem by reducing the error covariance matrix by empirical orthogonal functions (EOF) analysis. This assimilation method becomes applicable by keeping as statistical information only the predominant dynamic modes of the coupled systems. The SEEK filter gives a well-balanced compromise between computational limitations and robust statistical description of the system but leads to a drastic reduction of information that may not be sufficient to handle the complex behaviour of coastal ecosystems. The purpose of this paper is to present a novel methodology for the assimilation of SeaWiFS chlorophyll concentration maps into a three-dimensional-coupled hydrodynamic-biogeochemical model (3D Symphonie, Marsaleix et al., 2008, and Eco3M platform, Baklouti et al., 2006), to test the procedure and to discuss the substantial gain obtained by combining realistic simulations and field data.

\section{Materials and methods}

\subsection{The coupled model}

\subsubsection{Site description}

The Rhone delta-Gulf of Fos region is a shallow area located in the North-western Mediterranean Sea (Fig. 1). The semi-enclosed Gulf of Fos estuary covers approximately $40 \mathrm{~km}^{2}$ and is strongly affected by anthropogenic inputs due to intense river discharges. The major source of freshwater is the Rhone River which carries discharge of dissolved and particulate matter and potentially harmful substances into this region. Under certain discharge and wind conditions other less significant sources (Canal de Caronte in the East and dock 1 in the North) may also deliver freshwater and particles into Gulf of Fos (Ulses et al., 2005). Industrial activities along the gulf and upstream in the Rhone River determine in part the biogeochemical and physical properties of the inputs. The spatial configuration of the Rhone River plume is strongly linked to wind regimes (Broche et al., 1998; Estournel et al., 2001). The dominant northerly to north-westerly wind conditions (so-called 'Mistral') extend the Rhone River plume offshore southwestwards (Estournel et al., 1997). Intense but less frequent southerly to south-easterly winds constrain the plume against the coast and favour its intrusion into Gulf of Fos. High rates of primary production in this region are fuelled by nutrients from Rhone River inputs (Minas and Minas, 1989; Tett et al., 2003). Effects on biogeochemical dynamics linked to these inputs are generally included in the distal area which is a few dozens of kilometres further offshore (Naudin et al., 2001). The long residence times of water masses inside Gulf of Fos frequently lead to phytoplankton (PHYTO) biomass accumulation which enhances the risk of eutrophication phenomena (Tett et al., 2003). The phytoplankton biomass can thus be considered as a key parameter in understanding the ecosystem evolution inside the gulf.

External physical oceanographic processes take place in the area such as the "Northern Current" (Millot, 1990). Gulf of Fos is however relatively isolated from this slope current owing to its relatively narrow and shallow connection to the continental shelf.

\subsubsection{Coupled model description}

The coupling between physics and biogeochemistry was carried out in a classical online one-way forcing of the biogeochemical model by the circulation model. The coupling is represented by an advection-diffusion equation for the biogeochemical variables computed on the grid of the circulation model. A "forward" time stepping scheme was used with a time step of $82 \mathrm{~s}$. This equation included a sink-source term updated by the Eco3M platform every hour as well as a sedimentation term for particulate variables. Advection was computed using an upwind scheme while vertical diffusion used the mixing coefficient of the physical model.

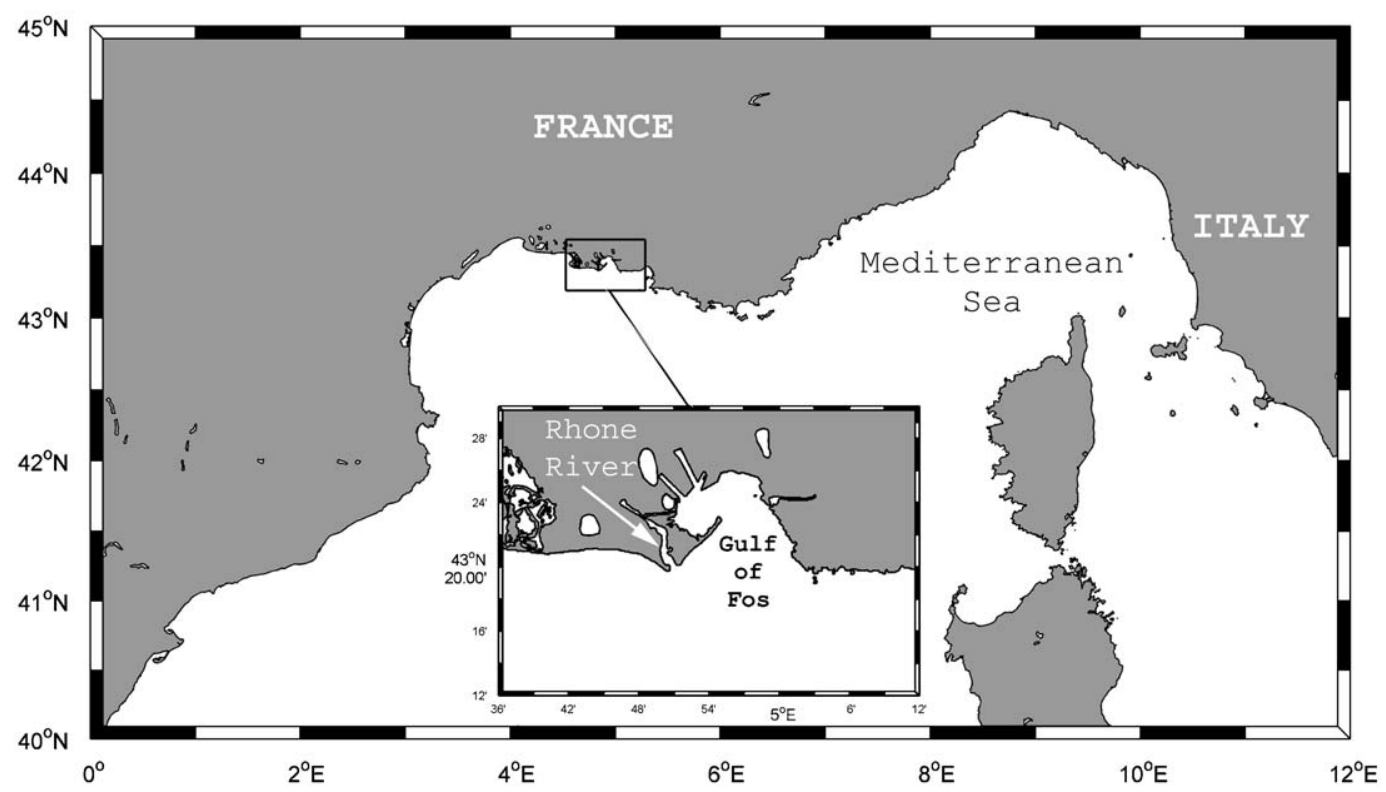

Fig. 1. Location of the Rhone River delta-Gulf of Fos system (North-western Mediterranean Sea). 


\subsubsection{The hydrodynamic model}

The hydrodynamic model used in this study is derived from Marsaleix et al. (2008). Physical variables as current, temperature, salinity and sea surface elevation were computed on a vertically staggered C-grid using a standard finite difference method (Arakawa and Lamb, 1977). The s-step coordinate system (Estournel et al., 2007) is a combination of the partial step coordinate system (Leitão et al., 2005) and the generalised terrain following coordinates (Ulses et al., 2008). The classical sigma coordinate systems possibly require smoothing of the model bathymetry in order to keep pressure gradient accuracy (Haney, 1991). The s-step coordinate enables more realistic bathymetry by locally changing the vertical sigma level corresponding to the bottom level when bottom slope is particularly strong. The s-step systems actually avoid the well-known "hydrostatic inconsistency" inconvenience of the sigma systems (Haney, 1991). The s-step coordinate was particularly useful in this study since the Gulf of Fos area has a complex bathymetry including navigation channels. Momentum, heat and salt fluxes were computed with the bulk formulae described in Estournel et al. (2007) using the sea surface temperature computed by the hydrodynamic model and the outputs of the meteorological ALADDIN model. Meteorological forcing were provided every $3 \mathrm{~h}$ on a $0.1^{\circ} \times 0.1^{\circ}$ horizontal grid.

The lateral open boundary conditions consisted of a barotropic Flather condition, a Sommerfeld equation for baroclinic currents and an advection condition for tracers (Marsaleix et al., 2006). These radiation conditions were combined with the external hydrodynamic forcing terms provided by a larger and coarser model, including a lateral nudging layer inside which inner solution was slowly relaxed toward forcing fields.

Freshwater inputs of the Rhone and Petit Rhone Rivers were introduced according to Estournel et al. (2001). The river discharges were provided daily by the Compagnie Nationale du Rhone (CNR).

A succession of nested models was used, starting with the Mediterranean basin scale model daily outputs delivered by the Mediterranean Forecasting System (MFS) project on a regular $0.125^{\circ} \times 0.125^{\circ}$ grid (Demirov and Pinardi, 2002). These fields provided the initial and boundary conditions of a North-western Mediterranean simulation computed by the Symphonie model using a $3 \mathrm{~km} \times 3 \mathrm{~km}$ grid. The outputs of this simulation were analysed for the 2001-2003 period by Bouffard et al. (2008). Finally a $1.5 \mathrm{~km} \times 1.5 \mathrm{~km}$ shelf scale model forced the study model centred on the Rhone delta-Gulf of Fos system, using a $500 \mathrm{~m} \times 500 \mathrm{~m}$ grid. Bathymetry of the modelled area is shown in Fig. 2.

\subsubsection{The biogeochemical model}

The biogeochemical model was based on a classical NPZD structure (e.g. Fasham et al., 1990) and described the nitrogen cycle of a pelagic food web through seven state variables (Diaz, 2000). The schematic block diagram of the model and the accounted processes are reported in Fig. 3. The pelagic ecosystem considered in this coastal area was modelled using a compartment of phytoplankton and of herbivorous/omnivorous zooplankton (ZOO). Two sources of dissolved organic nitrogen (nitrate, $\mathrm{NO}_{3}$, and ammonium, $\mathrm{NH}_{4}$ ) were included for phytoplankton growth. Several processes fed two compartments of particulate organic matter of different sizes $\left(\mathrm{POM}_{\mathrm{small}}<100 \mu \mathrm{m}\right.$ and $\left.\mathrm{POM}_{\text {large }}>100 \mu \mathrm{m}\right)$. These detritus were assumed to be converted directly into dissolved organic nitrogen (DON) without explicitly considering a microbial loop. Recycling of dissolved organic nitrogen provided ammonium. The latter was also supplied in part by zooplankton excretion. Nitrate was regenerated in the water column by the process of nitrification

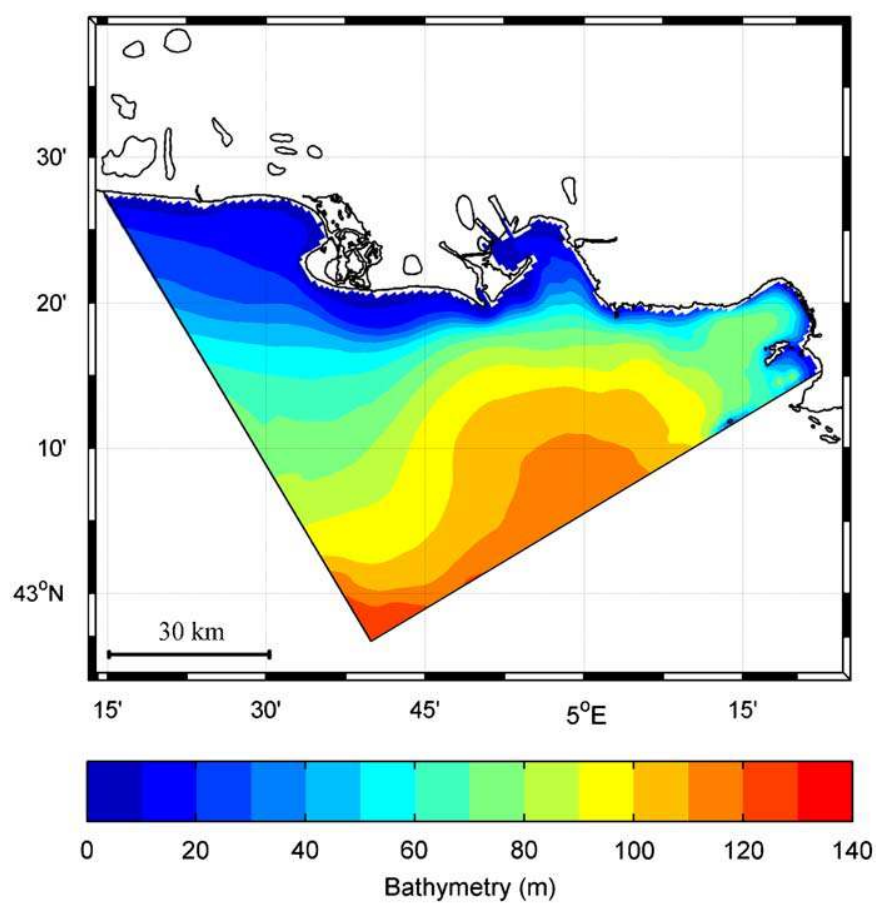

Fig. 2. Bathymetry of the modelled area.

which was implicitly treated in this study. The biogeochemical model was implemented in the Eco3M modelling platform (Baklouti et al., 2006). The biogeochemical state equations, the formulations of the different processes and parameter sets are presented in Appendix A (A.1-A.3). We deliberately choose a limited number of state variables for the biogeochemical model in order to allow an optimal interpretation of the assimilation efficiency for each state variable. Chlorophyll concentrations were simply derived from phytoplankton nitrogen concentrations using a Chl:N ratio equal to 2 (Van den Meersche et al., 2004; Moore et al., 2004).

The light attenuation with depth used a classical exponential law and was computed with a constant attenuation coefficient estimated from field observations $\left(K_{\text {dest }}=0.05 \mathrm{~m}^{-1}\right.$, Diaz, 2000). The effects of chlorophyll and turbidity on light attenuation have not been taken into account as no sedimentary model was used in this numerical configuration.

The coupled model was run from January 1, 2001 to May 1, 2001 to obtain stable initial biogeochemical conditions. Open boundary conditions (OBC) for nutrients were null conditions while other biogeochemical state variables used a null gradient condition. CNR provided monthly concentrations of particulate organic matter, dissolved organic matter and nutrients in rivers.

\subsection{Assimilation process}

\subsubsection{SEEK filter description}

The Ide et al. (1997) notation was adopted in presenting the SEEK filter in order to ensure consistency with contemporary publications. Detailed presentation of the filter can be found in Pham et al. (1998).

At time $t_{k}$, the system state $X^{a}$ is obtained by correcting the forecast state $X^{f}$ using the new observation $Y_{k}{ }^{o}$ :

$X^{a}\left(t_{k}\right)=X^{f}\left(t_{k}\right)+G_{k}\left(Y_{k}^{o}-H_{k} X^{f}\left(t_{k}\right)\right)$ 


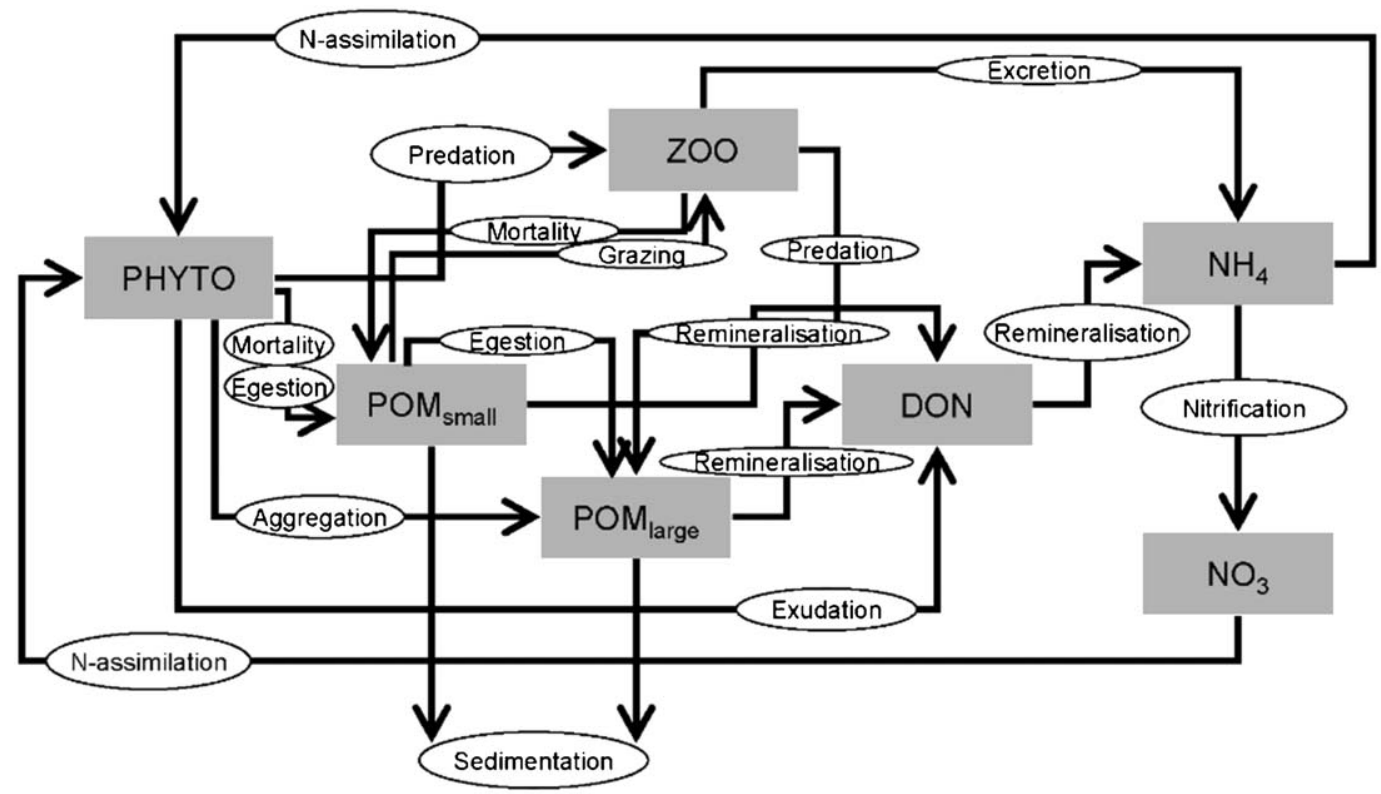

Fig. 3. Schematic representation of the biogeochemical model.

where $H_{k}$ is the observation operator and $G_{k}$ the gain matrix defined as:

$G_{k}=L U_{k} L^{T} \boldsymbol{H}_{\boldsymbol{k}}^{T} R_{k}^{-1}$

$\boldsymbol{H}_{\boldsymbol{k}}$ is the gradient of $H_{k}$ evaluated at $X^{f}\left(t_{k}\right), R_{k}$ is the observation error covariance matrix, $L$ the matrix containing the retained EOF's on its column and $U_{k}$ is computed by:

$U_{k}^{-1}=\left[U_{k-1}+\left(L^{T} L\right)^{-1} Q_{k}\left(L^{T} L\right)^{-1}\right]^{-1}+L^{T} H_{k}^{T} R_{k}^{-1} H_{k} L$

where $Q_{k}$ is the model error covariance matrix.

As proposed by Verron et al. (1999) the correction base was kept fixed during the assimilation period to limit computational cost. Finally, we assumed that the model was able to perfectly reproduce reality and thus the $Q$ matrix was defined as a null matrix and was not used in the filter calculations. A compensation technique in accordance with this hypothesis was proposed by Pham et al. (1998), consisting in the introduction of a 'forgetting factor' $\rho$ which artificially amplifies the background error covariance matrix.

$U_{k}$ is then given by:

$U_{k}^{-1}=\rho U_{k-1}^{-1}+L^{T} H_{k}^{T} R_{k}^{-1} H_{k} L$

The 'forgetting factor' was fixed at $\rho=0.6$ after several sensitivity tests. In the following experiment the state vector was composed of all biogeochemical variables from the threedimensional grid and the surface salinity. The observation vector was a combination of a satellite surface chlorophyll concentration map and a hydrodynamic model-extracted surface salinity map, considered as pseudo-data. The basic idea was to constrain the biogeochemical assimilation process with a plume-dependent physical variable, i.e. salinity. Assimilating surface pseudo-salinity allowed the SEEK filter through its EOF base to deal with the different biogeochemical dynamics between freshwater and deep water. In open sea waters supply of nutrients generally induces phytoplankton growth and biomass accumulation. High nutrient concentrations inside the Rhone River plume are not necessarily associated with high phytoplankton concentrations due to the short residence time of waters (Naudin et al., 2001). While surface salinity was integrated in the assimilation process, its value was not modified by the SEEK filter. In these conditions, the diagonal observation error covariance matrix (without cross-correlation) at time $t_{k}$ is defined as:

$\left.R_{k}=\begin{array}{cc}R_{k}^{c} & 0 \\ 0 & R_{k}^{S}\end{array}\right)$

where $R_{k}^{c}=\sigma^{c} I_{k}{ }^{o b s}, I_{k}{ }^{o b s}$ is the identity matrix of size $n_{k}{ }^{o b s}$ defined as the number of distinct chlorophyll concentration observations at time $t_{k}$ and $\sigma^{c}$ the chlorophyll observation error covariance parameter. The observation error covariance matrix for pseudosalinity at any time $t_{k}$ is $R_{k}{ }^{s}=R^{S}=\sigma^{S} I_{2 D}$ with $\sigma^{S}=1$ where $I_{2 D}$ represents an identity matrix of size $n_{2 D}$ defined as the number of surface grid points in the model. Readers should notice that parameters $\sigma^{c}$ and $\sigma^{s}$ have no physical units due to the normalisation of the EOF analysis. We then defined $\sigma_{s}^{c}=\sigma^{c} / \sigma^{s}$ which could be considered as a fictive ratio between the error covariance of chlorophyll and pseudo-salinity. As this ratio decreased the absolute value of corrections applied to biogeochemical variables increased. In other words, lower values of this parameter led to less trust being placed in the pseudo-salinity measurements. The assimilation scheme then had a higher degree of freedom with respect to biogeochemical corrections with $\sigma_{s}^{c}$ acting as a free parameter which tunes the trust given to assimilation. This method of assimilating surface pseudo-salinity was needed to keep the biogeochemical dynamics realistic. Hereafter $\sigma_{s}{ }^{c}$ will be called "covariance ratio" and its precise role will be described later in this paper.

The filter was localised as described in Testut et al. (2003). The assimilation scheme was an independent application of SEEK filters on distinct overlapped sub-domains. The first advantage of this domain definition was to naturally limit the observation correlation between distant places. Second, it allowed an application of the method on standard computing system.

EOF base was constructed by running the model during April and May 2001 and holding a full state vector every $12 \mathrm{~h}$.

\subsubsection{The assimilated data set}

Data assimilated in this study were derived from SeaWiFS remotely sensed reflectance of merged local average cover (MLAC) products offering a maximum resolution of $1.1 \mathrm{~km} \times 1.1 \mathrm{~km}$ (Feldman and McClain, 2007). Chlorophyll concentrations were computed using the five-band optical algorithm named OC5 


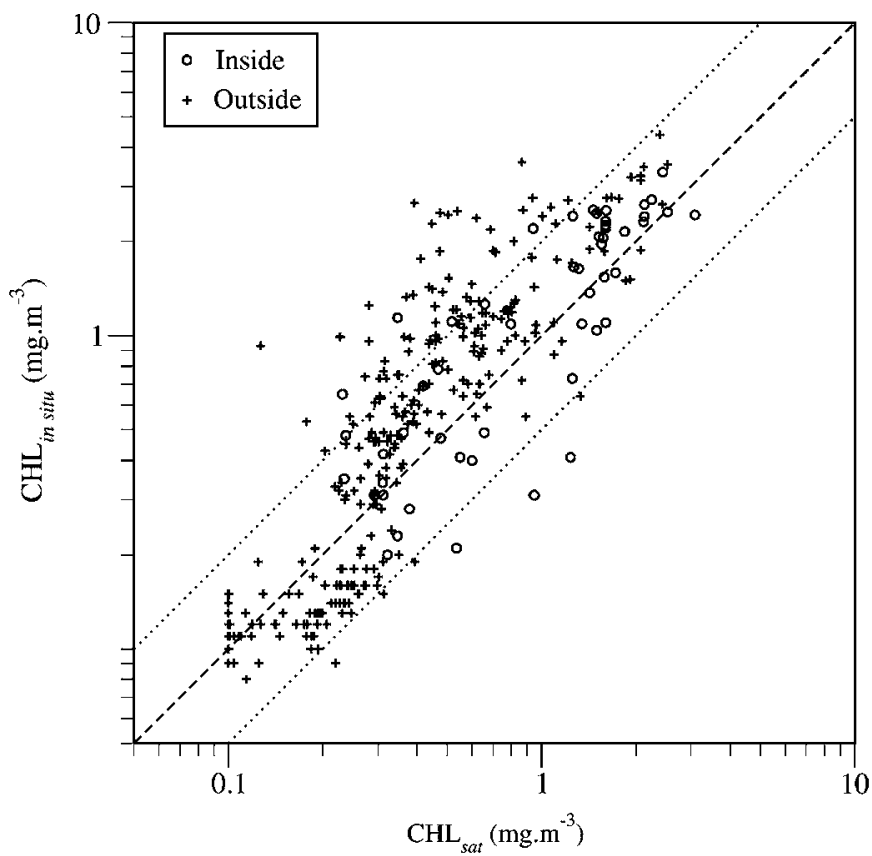

Fig. 4. Comparison between in situ measurements and satellite estimation of surface chlorophyll concentrations on the Gulf of Lion. Data measured inside and outside the model grid are represented as circles and crosses, respectively.

(Gohin et al., 2002, 2005). Satellite-estimated chlorophyll concentrations were compared with in situ measurements performed during the SARHYGOL cruise (Ouillon and Petrenko, 2002) which took place on several days of years 2000 and 2001 in the Gulf of Lions. On the whole SARHYGOL data set, 332 values of surface chlorophyll concentrations were compared to SeaWiFS-OC5 data. This comparison is shown in Fig. 4 where both in situ measurements inside and outside the model domain are represented. The absolute percentage difference (APD $=39.9 \%$ ) might be the best we could expect in such coastal areas submitted to strong variability of optical properties due to high contents in suspended particulate matter. This potential high concentration in sediment is a well-known characteristic of coastal case 2 waters. In these areas, optical signal measured can be a combination of both chlorophyll pigment and inorganic suspended matter. The main advantage of the OC5 algorithm applied here is to isolate the signal of the chlorophyll pigment. A strong influence of sediments should also imply a systematic overestimation of the satellite-observed chlorophyll concentration. This was not a major problem in our case according to Fig. 4.

One should be aware of the discrepancy between punctual in situ measurements and the $1.1 \mathrm{~km} \times 1.1 \mathrm{~km}$ remotely estimated data. In situ measurements were performed during the daytime while satellite maps were provided at approximately 12:00. The mismatch between satellite data and in situ measurements was a maximum of $12 \mathrm{~h}$.

From May 1, 2001 to May 22, 2001, 8 chlorophyll maps were visually selected as able to be assimilated due to their accurate coverage regarding the modelled domain.

\section{Data assimilation experiment}

\subsection{Simulation conditions}

The simulation period was from May 1, 2001 to May 22, 2001. This period corresponds to the ModelFos cruise carried out in Gulf of Fos. On May 12, 14 and 16, in situ measurements of chlorophyll,

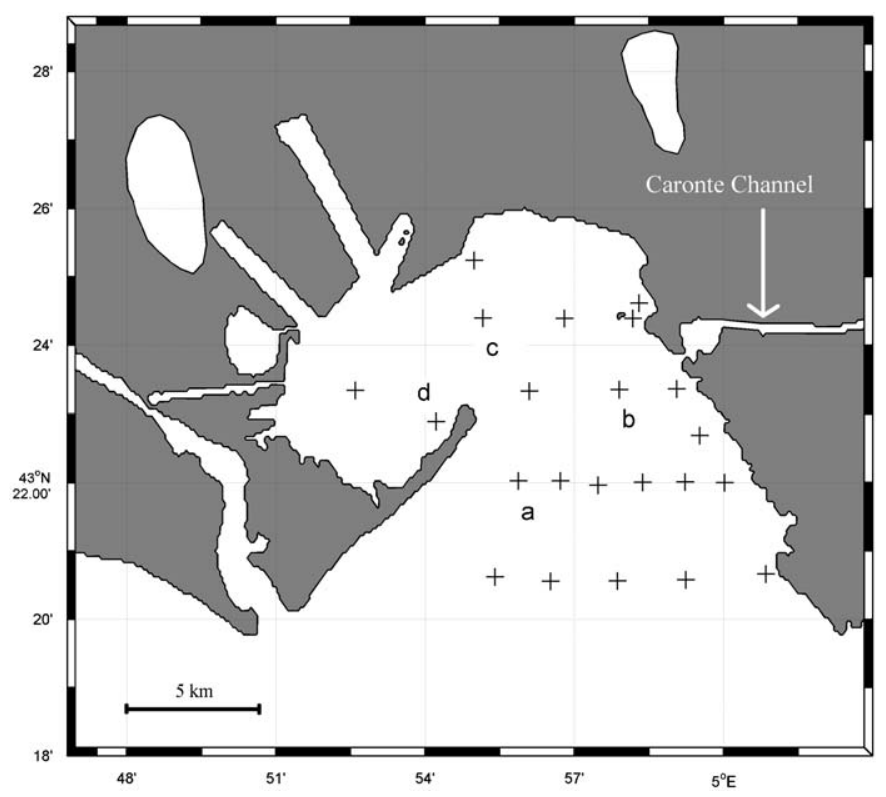

Fig. 5. Location of sampling stations during ModelFos cruise.

nitrate and ammonium concentrations were performed on a regular grid of 22 stations. This data set was used to evaluate the efficiency on "assimilation-observed variable" (chlorophyll) but also on "assimilation-non-observed variables" (nutrients). Readers should note that in situ data were not used in the assimilation process. Starting from a stabilised state on May 1, a "free" simulation (without any assimilation) was performed. The latter was compared to new simulations starting at the same state on May 1, but assimilating available chlorophyll concentration maps on May 3, 5, 8, 12, 15, 18 and 19. This run will be referred to hereafter as the 'SEEK' run.

\subsection{Sensitivity to the covariance ratio}

To set the covariance ratio $\sigma_{s}^{c}$, a comparison of assimilation efficiency was established with respect to this parameter. Four experimental stations out of 22 from the ModelFos dataset, referred alphabetically (Fig. 5) will be used in the discussion. Fig. 6 shows a comparison between the free run and several assimilated runs on station ' $b$ ' using different significant values of $\sigma_{s}^{c}$ for surface chlorophyll concentrations.

While a ratio of $10^{-2}$ and $10^{-3}$ described similar dynamics in agreement with a high increase in chlorophyll concentrations measured in situ between May, 12 and 16, a ratio of $10^{-4}$ resulted in a decrease in the assimilation efficiency. A covariance ratio that tended towards a higher value than $10^{-2}$ limited the absolute value of correction brought by the filter (not shown). When the covariance ratio tended towards a low value, the assimilation process tended to a case where the salinity was not considered in the observation vector. In the latter case conceptual problems appeared due to differences in the biogeochemical dynamics in fresh and open sea waters. EOF analysis accurately represents the rapid increase of phytoplankton growth and biomass following an increase in nutrient concentrations in the open sea. The Rhone River supplies important inputs of nutrients but in the vicinity of its mouth phytoplankton concentrations are very low. The filter correction tended then to decrease nutrient concentrations in this area, in contradiction with usual observations. Fig. 7(1-3) shows modelled surface nitrate concentrations on May 3, at 12:00 am, for the free run (1), the assimilated run with $\sigma_{s}{ }^{c}=10^{-3}$ (2) and 


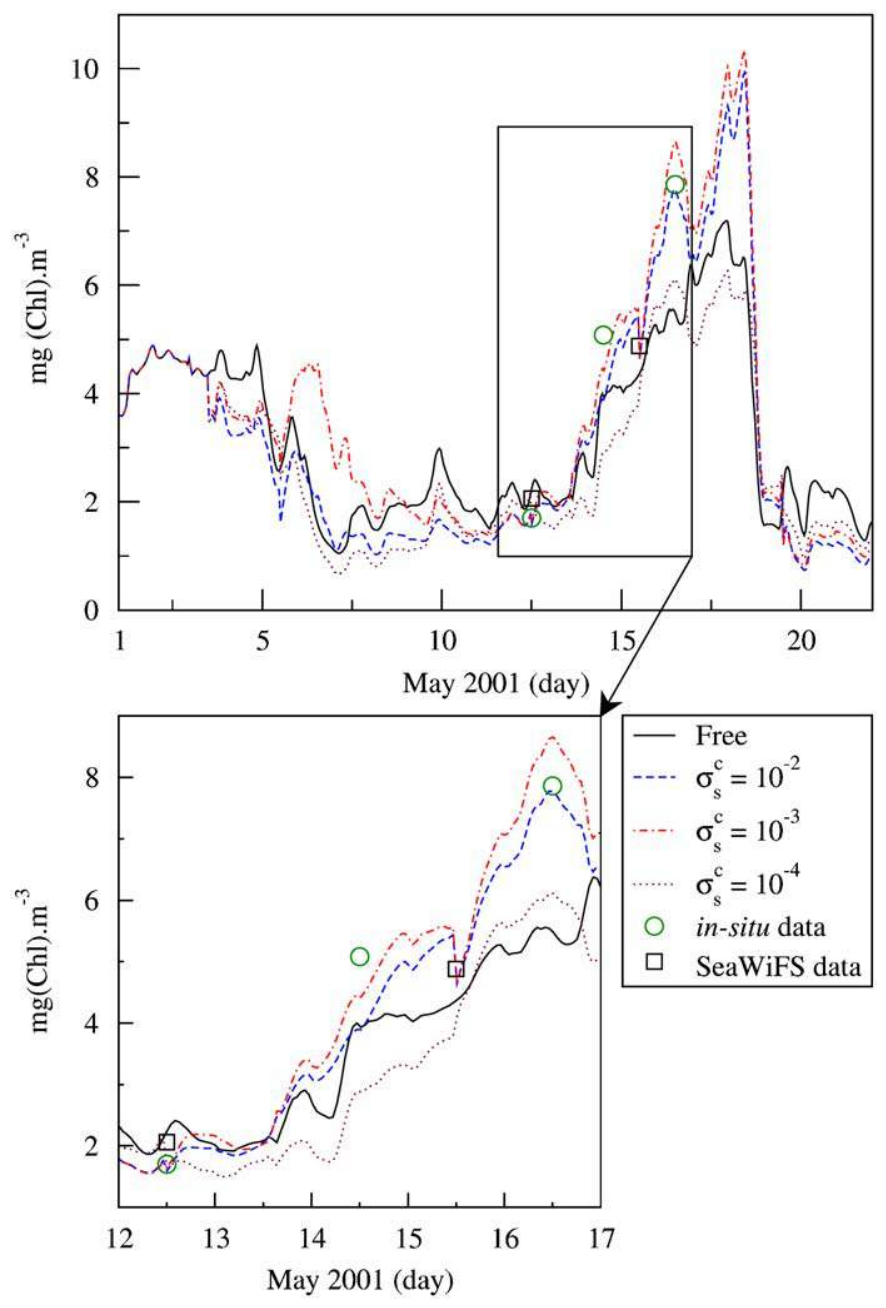

Fig. 6. Temporal evolution of surface chlorophyll concentrations at station (b) for the free run and assimilated runs using several values of covariance ratio $\sigma_{s}^{c}$. In situ data are represented as circles and satellite estimation as squares. Period of interest is reported in a frame.

the assimilated run with $\sigma_{s}^{c}=10^{-4}$ (3), respectively. A value of $10^{-3}$ deeply modified the spatial configuration of the river plume (Fig. 7(2)) while keeping realistic concentrations of nitrate near the Rhone River mouth. When pseudo-salinity influenced the observation vector less (by giving a low value to chlorophyll observation error covariance), concentrations of nitrate fell to close to zero inside the Rhone River plume (Fig. 7(3)). This sensitivity test showed the lower the salinity constraint, the more the nutrient contents modelled in the river plume are unrealistic implying lower performances of the coupled model.

Considering this balance between freedom and conceptual limits of the assimilation process, the covariance ratio $\sigma_{s}^{c}$ was fixed at $10^{-3}$ for the rest of the assimilation experiment.

\subsection{Assimilation efficiency in time}

Measurements at different depths of the water column were made during the ModelFos cruise. Available data for chlorophyll, nitrate and ammonium concentrations were compared to the free and the SEEK runs. Three different water levels: surface, middle depth and bottom are shown in Figs. 8-10 (L1, L2 and L3, respectively). No in situ bottom samples were taken for station ' $d$ '.

The period between May 12 and 17 in general is characterised by an increase in nitrate and chlorophyll over the whole water
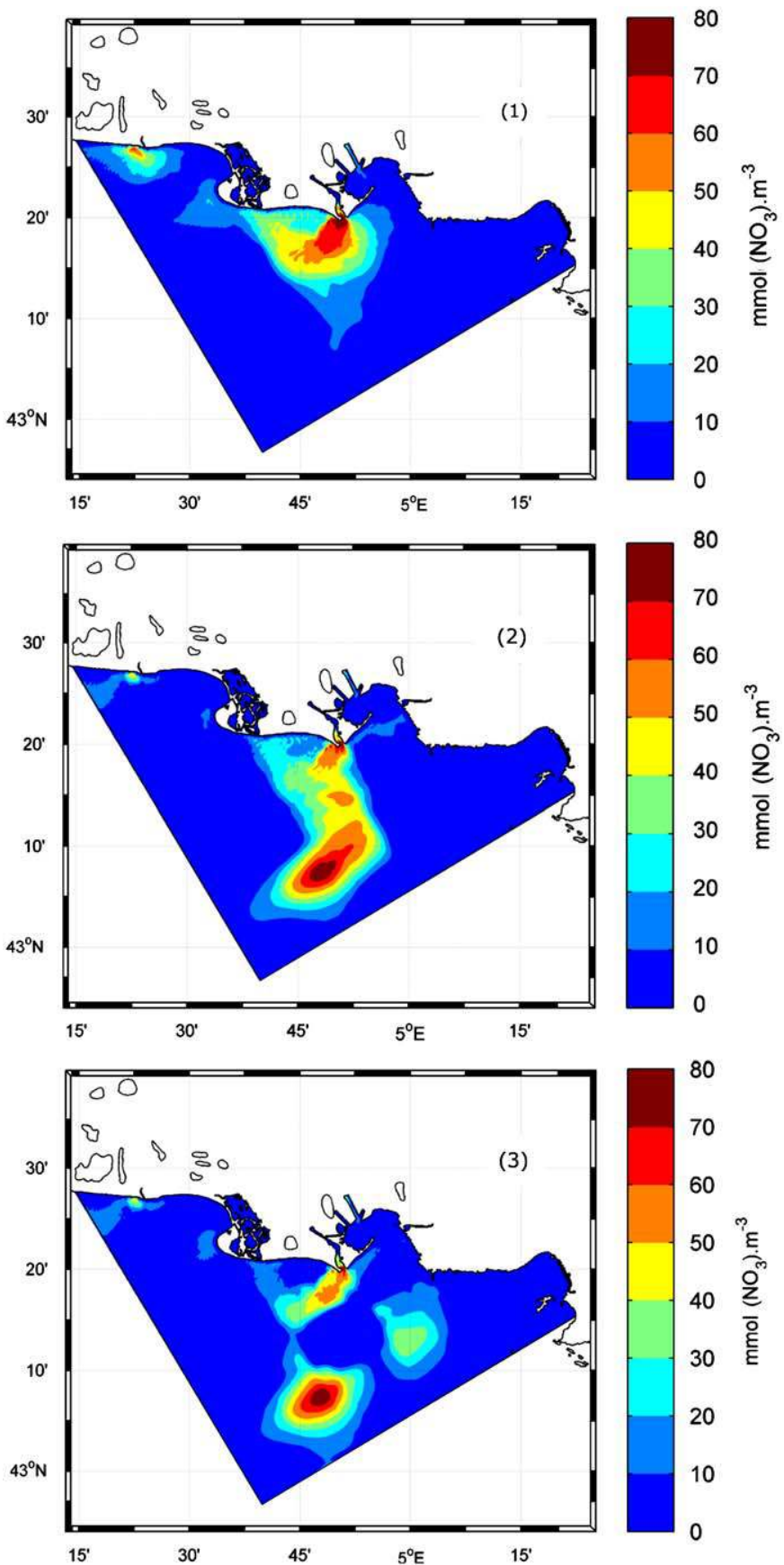

Fig. 7. Spatial distribution of surface nitrate concentration on May 3, 2001 at 12:00 am. (1) Free run. (2) Assimilated run with $\sigma_{s}^{c}=10^{-3}$. (3) Assimilated run with $\sigma_{s}^{c}=10^{-4}$

column as shown by the in situ and satellite derived data. This evolution is relatively well reproduced by the free run indicating that the few state variables and processes used in the biogeochemical model were satisfactory. The assimilation of chlorophyll maps resulted in an increase in concentrations of all the state variables over the whole period, except surface chlorophyll during the two first day period (L1, Fig. 8). During this period modelled surface chlorophyll was globally overestimated (stations 'a', 'b', 'c') when compared to data. It is noteworthy that both satellite a nd in situ chlorophyll were similar on May 12. The use of the SEEK filter (dashed line) lowered the modelled chlorophyll, giving better agreement with data. 

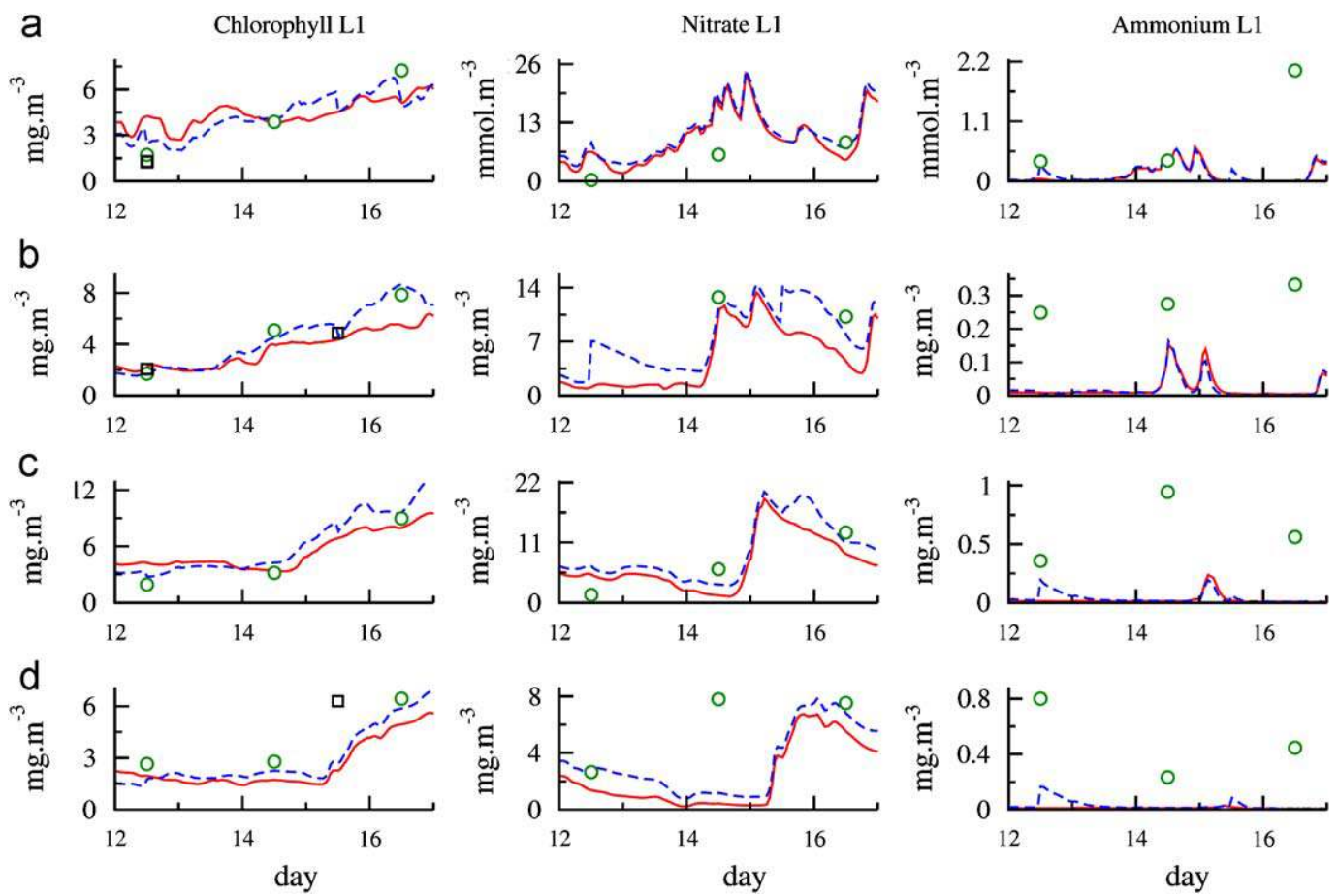

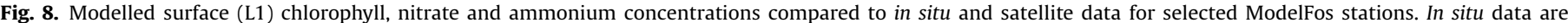
represented as circles and satellite estimation as squares (free run: continuous line; SEEK filter: dashed line).
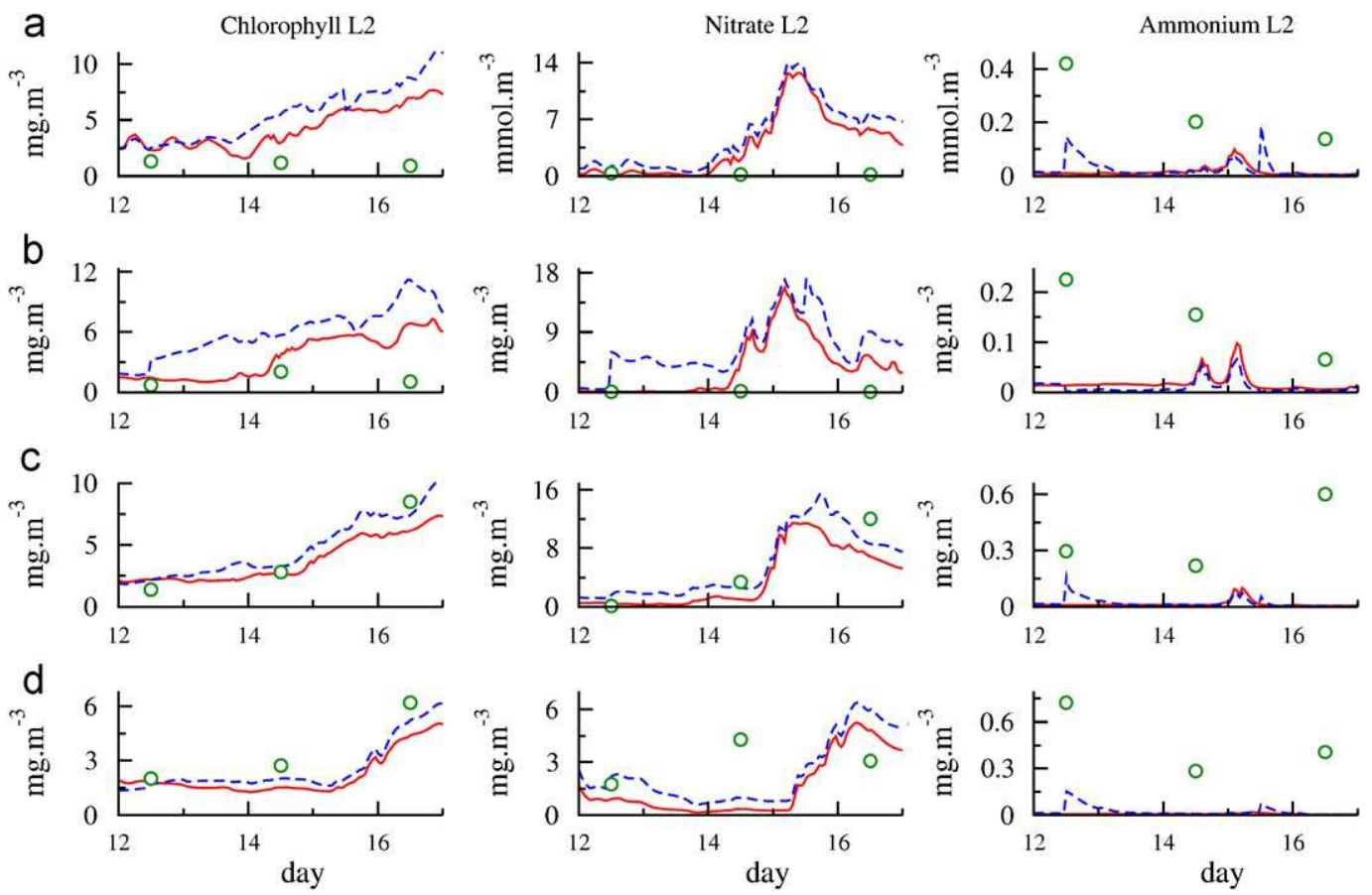

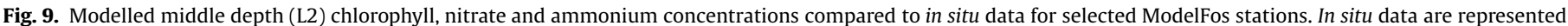
as circles (free run: continuous line; SEEK filter: dashed line).

Station 'b' is located near the Caronte channel mouth that connects Berre lagoon to Gulf of Fos in the East. The dimension of Caronte channel is about the same order of magnitude as the model cells so this channel was not considered in our coupled model. A substantial improvement was obtained thanks to assimilation when comparing surface concentration of nitrate between May 14 and 16 on station 'b'. Corrections brought by the filter during that period induced an increase in nitrate close to the observed concentrations, improving the overall model outputs for the chlorophyll concentrations. This shows that a lack of boundary forcing (nitrate inputs from Berre Lagoon) was positively corrected. The assimilation effects on the middle part of the water column were mixed (Fig. 9) when considering all variables. The SEEK filter correction degraded the behaviour of the model at the bottom of the water column (Fig. 10). 

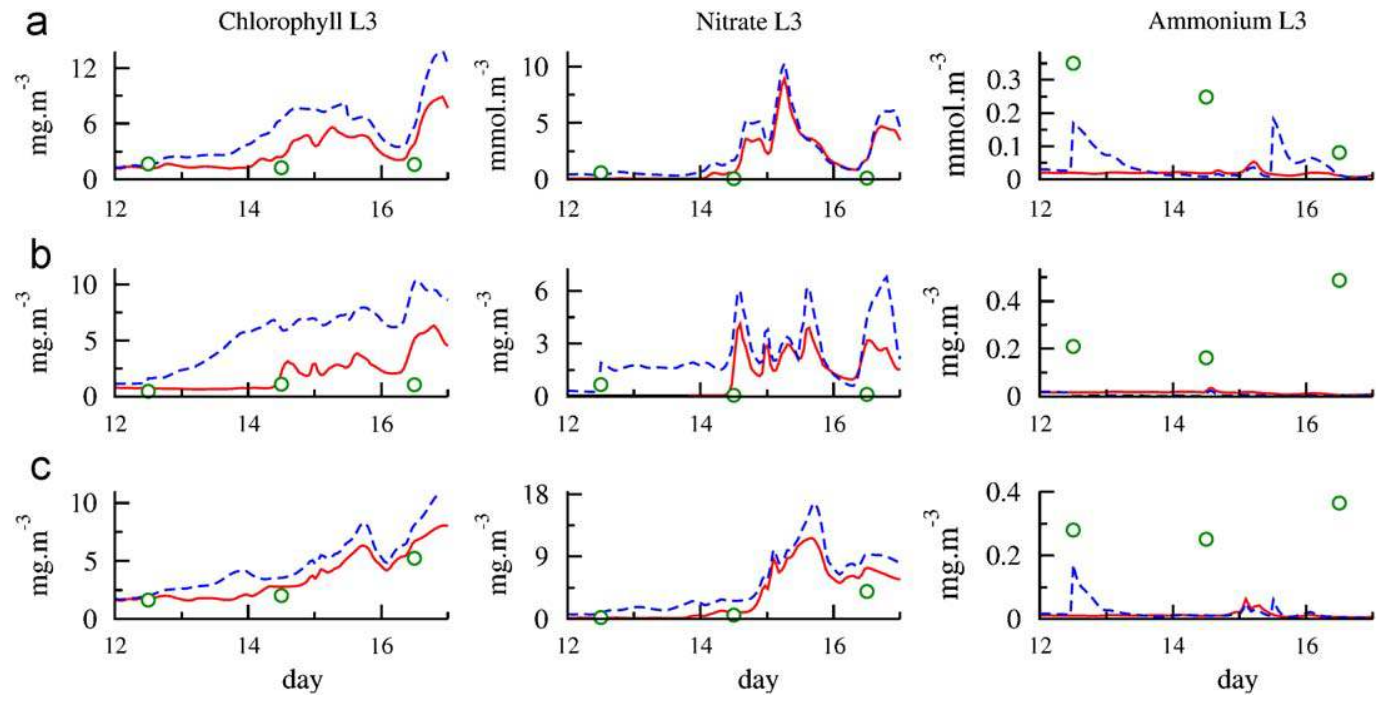

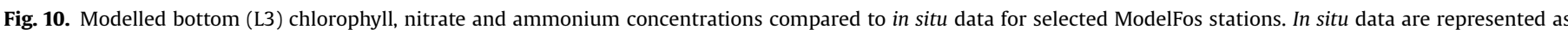
circles (free run: continuous line; SEEK filter: dashed line).

The simulation of ammonium contents by the coupled model was clearly not satisfactory. Application of the SEEK method did not improve the model outputs. This may be because the strong mismatch between temporal variations of ammonium contents and the rhythm of use of the SEEK filter. The turnover time of ammonium cycles is generally observed to range from minutes to hours (e.g. Eppley et al., 1979; Harrison 1993) which is much faster than the time between two successive assimilations of chlorophyll maps (typically 3 days during ModelFos cruise). As an example at stations 'a', 'c', 'd' (all levels), the strong corrections applied by the SEEK filter on ammonium was quickly decreased to a null value about 1 day later. Nevertheless, ammonium contents were low compared to nitrate in both measured and simulated data. Primary production benefited more from nitrate given the difference of one to several orders of magnitudes between these two nutrients.

Based on Fig. 6 showing the surface chlorophyll for the free and the SEEK runs for $\sigma_{s}^{c}=10^{-3}$ we can discuss the gain obtained by the assimilation process. The first assimilation step on May 3 is clearly visible as free and SEEK runs differ from that date on. Differences between the free and the SEEK runs were slight during about 9 days (from May 3 to May 12) and higher during the period of chlorophyll increase (from May 12 to May 17). On May 16 at 12:00 am the SEEK run predicted a chlorophyll concentration of $8.5 \mathrm{mg} \mathrm{m}^{-3}$, measurements showed a value of $7.8 \mathrm{mg} \mathrm{m}^{-3}$, while the free run predicted a value of $5.4 \mathrm{mg} \mathrm{m}^{-3}$. During the same period for surface nitrate (Fig. 8, Nitrate L1) at station ' $b$ ', the free run predicted a concentration of $4.2 \mathrm{mmol} \mathrm{m}^{-3}$, the SEEK run a value of $7.7 \mathrm{mmol} \mathrm{m}^{-3}$ and measurements a value of $10.2 \mathrm{mmol}$ $\mathrm{m}^{-3}$. These examples show how short-term predictions can be improved by assimilating satellite surface chlorophyll data into a coastal coupled physical-biogeochemical model.

Table 1 shows a variable-averaged error rate $R$ between assimilated run and free run for both analysis and forecast cases. The analysis rate was computed just after the assimilation steps while the forecast rate was computed just before. The rate of a variable $R_{\mathrm{var}}$ was defined as follows:

$R_{\mathrm{var}}=\frac{N_{\mathrm{var}}}{N_{\text {tot }}} \sqrt{\frac{\sum\left(C_{\mathrm{var}}^{\text {SEEK }}-C_{\mathrm{var}}^{\text {data }}\right)^{2}}{\sum\left(C_{\mathrm{var}}^{\text {free }}-C_{\mathrm{var}}^{\text {data }}\right)^{2}}}$

where $R_{\mathrm{var}}$ is associated to variable 'var' (chlorophyll, nitrate or ammonium). $N_{\text {var }}$ is the number of data available for the
Table 1

Mean averaged differences between assimilated and free run (analysis and forecast) for the three sampling depths.

\begin{tabular}{llll}
\hline & $R_{\mathrm{L} 1}$ & $R_{\mathrm{L} 2}$ & $R_{\mathrm{L} 3}$ \\
\cline { 2 - 4 } & 0.96 & 1.22 & 1.33 \\
Analysis & 0.90 & 1.14 & 1.25 \\
Forecast & &
\end{tabular}

corresponding variable and $N_{\text {tot }}$ the total number of data. $C_{\mathrm{var}}^{\text {run }}$ is the concentration of the variable 'var' for the free run ('free') and the assimilated run ('SEEK'). The mean $R$ for a given level is then

$R_{\text {level }}=R_{\text {chl }}+R_{\text {nitrate }}+R_{\text {ammonium }}$

where only data of the chosen level entered the computation. This rate was an estimator of the assimilation process efficiency on model agreement with data. A perfect correction should lead to $R=0$. If the SEEK assimilation has made the agreement between simulation and in situ data worse, then $R$ should be higher than 1 . A $R<1$ inversely shows that the assimilation improved matching between simulated and measured concentrations values.

Table 1 shows clearly that the model error was on average decreased on surface data $\left(R_{\mathrm{L} 1}<1\right)$. The gain in forecasting potential was then about $10 \%$. Inversely, inside the water column, the model values diverged from the measured data $\left(R_{\mathrm{L} 2}\right.$ and $\left.R_{\mathrm{L} 3}\right)$, suggesting that assimilation of in situ data from the entire water column is essential in order to set up an efficient biogeochemical operational modelling system. The assimilation performance decreased with the depth considered in the water column for both analysis and forecast cases. This result was expected as the information assimilated came from the top of the water column.

\subsection{Assimilation efficiency in space}

Fig. 11(1) represents the surface chlorophyll on May 12 at 12:00 for the free run. Fig. 11(2) shows the surface satelliteestimated chlorophyll concentrations available at 11:54 on the same day. Flagged data due to cloud cover or unusable values of water leaving irradiance are delimited by a thick line. Differences in the spatial distribution and contents between the free run and the satellite data were relatively important. Chlorophyll 

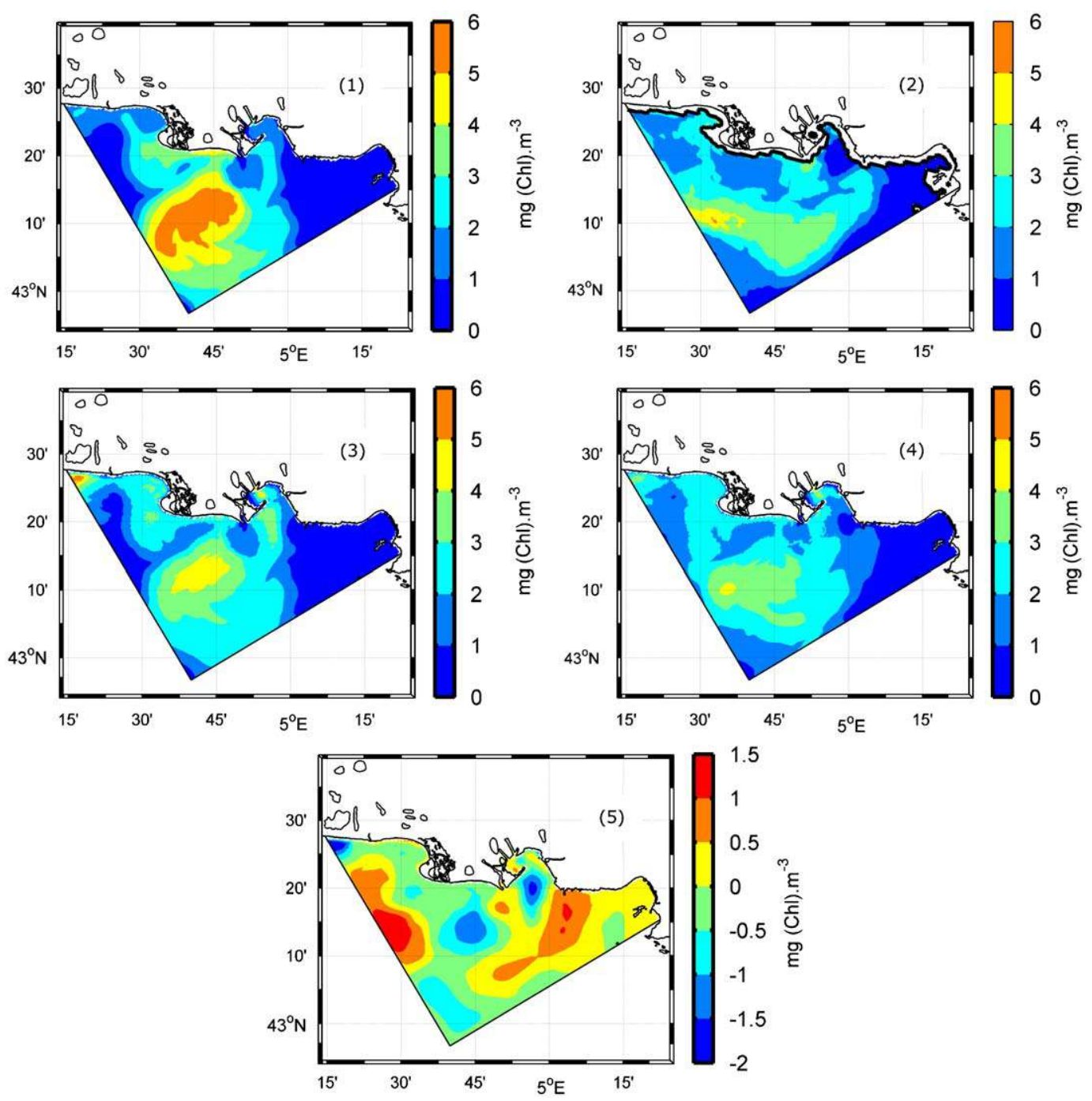

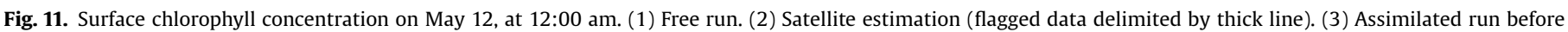
SEEK correction. (4) Assimilated run after SEEK correction. (5) SEEK correction.

concentrations inside the Rhone River plume were largely overestimated by the free run and divergences appeared in the eastern and western parts of the domain. Fig. 11(3) shows the SEEK run surface chlorophyll concentrations just before analysis of the system state by the filter (11:54). The previous assimilation was on May 8 around 12:00, 4 days before the satellite image was available. Even before the assimilation step on May 12, chlorophyll concentrations corrected by the SEEK filter were globally closer to observations compared to the results of the free run. After the next assimilation step on May 12, simulated surface chlorophyll concentrations were almost equivalent to satellite observations (Fig. 11(4)). Fig. 11(5) shows the algebraic correction brought by the filter on modelled surface chlorophyll contents. The assimilation process modified the spatial configuration of the chlorophyll plume in the western part of the domain.

Thus, the assimilation scheme used here proved to be efficient in significantly improving the predictions of spatial distributions of chlorophyll concentrations in freshwater-influenced ecosystems.

\section{Conclusion}

A SEEK filter was used to integrate remotely sensed chlorophyll data into a coupled physical-biogeochemical model applied to the
Gulf of Fos-Rhone River delta system. Particular care was taken to ensure a maximum reliability of satellite data used in the assimilation process. The optical OC5 algorithm applied to SeaWiFS MLAC products was found to provide an optimal agreement with a high number of in situ measurements in the study area. We used ModelFos data sampled during a cruise carried out in Gulf of Fos as an independent data set in order to estimate the assimilation process efficiency on biogeochemical variables. An innovative approach was to add surface salinity in the state vector allowing the filter to deal with different dynamics inside and outside the Rhone River plume. The data integration process was found to be extremely useful in respecting the biogeochemical dynamics of the studied area. A missing boundary condition (Caronte channel inputs) led to large divergences between in situ data and free run simulations (without assimilation). These divergences were corrected by the assimilation technique. The ability of the coupled model to predict biogeochemical variables was significantly improved even over a period of few days without available data for assimilation. The model behaviour in the deeper part of the domain was nevertheless poorer than at the surface and efficiency of satellite chlorophyll data assimilation was not proved inside the water column.

Limitation of the method was pointed out by the fact that an erroneous description of the ammonium contents by the coupled 
model could not be corrected by the assimilation process applied here. Simulated ammonium concentrations were much lower than nitrate concentrations during this period. It appeared that the time elapsed between two available satellite images should not exceed 1 day to keep a coherent correction on variables with rapid turnover times like ammonium. A way to overcome this problem could be the assimilation of high frequency in situ measurements of these variables. Further tests with our assimilation scheme could help in defining an optimal monitoring system.

The temporal evolution of simulated surface chlorophyll at a given station for the whole modelled period showed the realistic response of the coupled model to the assimilation process in close agreement with measured values.

From a spatial point of view, we showed the value of applying the SEEK filter correction by comparing surface chlorophyll concentration given by the satellite observations, free model run and the assimilated model runs. The model predictions were markedly improved even after a 4-day period without assimilation. After an assimilation step, the surface chlorophyll concentration map was corrected further, resulting in a high similarity between remotely estimated and modelled chlorophyll fields.
We chose a basic approach for sequential data assimilation scheme. The SEEK filter balance between system description and practical numerical implementation seems one of the most appropriate in this context.

\section{Acknowledgements}

This work was carried out in the frame of the European project INSEA, Data Integration System for Eutrophication Assessment in Coastal Waters, Contract SST4-CT-2005-012336. We thank MétéoFrance for the ALADDIN model outputs and the Compagnie Nationale du Rhône for data on river discharges. We thank NASA for providing us ocean colour data through their website http:// oceancolor.gsfc.nasa.gov. We appreciate the valuable assistance of captain and crew of the Research Vessel Tethys II (INSU-CNRS) during the 2001 ModelFos cruise. We thank Anne Petrenko for providing the SARHYGOL data set. We finally are grateful to Francis Gohin for the OC5 algorithm he provided to compute the assimilated data set.

\section{Appendix A.1. Description of the state equations used for the biogeochemical model}

Phytoplankton

$\frac{\partial[\text { PHYTO }]}{\partial t}+\frac{\partial(u[\text { PHYTO }])}{\partial x}+\frac{\partial(v[\text { PHYTO }])}{\partial y}+\frac{\partial\left(w-w_{\text {phyto }}[\text { PHYTO }]\right)}{\partial z}=\frac{\partial}{\partial z}\left(K_{v} \frac{\partial[\text { PHYTO }]}{\partial z}\right)$
$+N_{3}^{\text {uptake }}+N_{4}^{\text {uptake }}-D^{\text {up }} N_{N_{4}}^{\text {exudation }}-D^{\text {exudation }}-G R N_{N_{3}}^{\text {PHYTO }}-A G G^{\text {PHTYTO }}-M O R T^{\text {PHYTO }}$

Zooplankton

$\partial \frac{[Z O O]}{\partial t}+\frac{\partial(u[Z O O])}{\partial x}+\frac{\partial(v[Z O O])}{\partial y}+\frac{\partial(w[Z O O])}{\partial z}=\frac{\partial}{\partial z}\left(K_{v} \frac{\partial[Z O O]}{\partial z}\right)$

$+G R A Z^{P H Y T O}+G R A Z^{P O M_{\text {small }}}-E G E^{P H Y T O}-E G E^{P O M_{\text {small }}}-E X C_{N_{4}}-P R E D^{Z O O}-M O R T^{Z O O}$

Nitrate

$\frac{\partial\left[N_{3}\right]}{\partial t}+\frac{\partial\left(u\left[N O_{3}\right]\right)}{\partial x}+\frac{\partial\left(v\left[N O_{3}\right]\right)}{\partial y}+\frac{\partial\left(w\left[N O_{3}\right]\right)}{\partial z}=\frac{\partial}{\partial z}\left(K_{v} \frac{\partial\left[N O_{3}\right]}{\partial z}\right)$

$+\mathrm{NIT}-\mathrm{NO}_{3}^{\text {uptake }}$

Ammonium

$\frac{\partial\left[N H_{4}\right]}{\partial t}+\frac{\partial\left(u\left[N H_{4}\right]\right)}{\partial x}+\frac{\partial\left(v\left[N H_{4}\right]\right)}{\partial y}+\frac{\partial\left(w\left[N H_{4}\right]\right)}{\partial z}=\frac{\partial}{\partial z}\left(K_{v} \frac{\partial\left[N H_{4}\right]}{\partial z}\right)+R E M^{D O N}+E X C_{N H_{4}}-N H_{4}^{u p t a k e}-N I T$

Small particulate organic matter

$\left.\frac{\partial\left[P O M^{\text {small }}\right]}{\partial t}+\frac{\partial\left(u\left[P O M^{\text {small }}\right]\right)}{\partial x}+\frac{\partial\left(v\left[P O M^{\text {small }}\right]\right)}{\partial y}+\frac{\partial\left(w-w_{P O M^{\text {small }}}\left[P O M^{\text {small }}\right]\right)}{\partial z}=\frac{\partial}{\partial z} K_{v} \frac{\partial P O M^{\text {small }}}{\partial z}\right)$

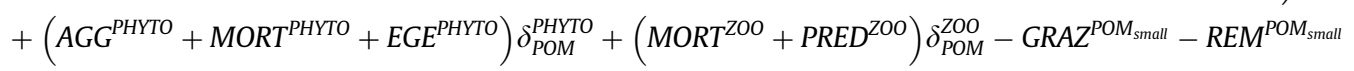

Large particulate organic matter

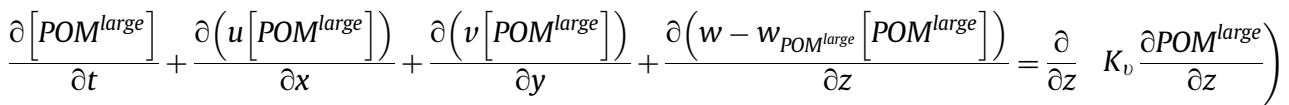

$+\left(A G G^{\text {PHYTO }}+M O R T^{\text {PHYTO }}+E G E^{\text {PHYTO }}\right)\left(1-\delta_{\text {POM }}^{\text {PHYTO }}\right)+E G E^{\text {POM }}$ small

$+\left(M O R T^{Z O O}+P R E D^{Z O O}\right)\left(1-\delta_{P O M}^{Z O O}\right)-R^{Z} M^{P^{P O M} \text { large }}$

Dissolved organic matter

$\frac{\partial[D O N]}{\partial t}+\frac{\partial(u[D O N])}{\partial x}+\frac{\partial(v[D O N])}{\partial y}+\frac{\partial(w[D O N])}{\partial z}=\frac{\partial}{\partial z}\left(K_{v} \frac{\partial[D O N]}{\partial z}\right)$

$D O N_{\mathrm{NH}_{4}}^{\text {exudation }}+\mathrm{DON}_{\mathrm{NO}_{3}}^{\text {exudation }}+R E M^{\mathrm{POM}_{\text {small }}}+R E M^{\mathrm{POM}_{\text {large }}}-R E M^{D O N}$ 


\section{Appendix A.2. Mathematical formulation of the biogeochemical processes}

Phytoplankton

Nutrients uptake

$N O_{3}^{\text {uptake }}=\mu^{\text {growth }} \frac{N_{3}}{k_{N_{3}}+N O_{3}}\left(1-\frac{I_{m} N H_{4}}{k_{I}+N H_{4}}\right) f(T) \cdot f(P A R)[$ PHYTO $]$

$\mathrm{NH}_{4}^{\text {uptake }}=\mu^{\text {growth }} \frac{\mathrm{NH}_{4}}{k_{\mathrm{NH}_{4}}+\mathrm{NH}_{4}} f(T) f(P A R)[$ PHYTO $]$

Dissolved organic nitrogen exudation

$\mathrm{DON}_{\mathrm{NO}}^{\text {exudation }}=\gamma_{\mathrm{NOD}} \mathrm{NO}_{3}^{\text {uptake }}$

$\mathrm{DON}_{\mathrm{NH}_{4}}^{\text {exudation }}=\gamma_{\mathrm{NOD}} \mathrm{NH}_{4}^{\text {uptake }}$

Limitation by temperature

$f(T)=a_{T}^{\left(T-T_{\text {OPT }}\right)}$

Limitation by light

$f(P A R)=\left(1-e^{-\frac{P A R(2)}{K_{P A R}(T)}}\right) e^{-\beta \cdot \frac{P A R(z)}{K_{P A R}(T)}}$

$K_{P A R}(T)=K_{P A R}\left(T_{O P T}\right) f(T)$

Aggregation loss

$A G G^{\text {PHYTO }}=a_{\text {PHYTO }}[\text { PHYTO }]^{2}$

Mortality loss

MORT $^{\text {PHYTO }}=m_{\text {PHYTO }}[$ PHYTO $]$

Zooplankton

Grazing

$G R A Z^{X}=g_{\text {MAX }} f(T) I_{X} \frac{[X]}{k_{Z}+p^{P H Y T O}[P H Y T O]+p^{P O M_{\text {small }}\left[\text { POM }_{S M A L L}\right]}} \quad$ with X $=$ PHYTO or POM small

and $p^{P O M_{\text {small }}}=1-p^{P H Y T O}$

$I^{X}=\frac{p^{X}[X]}{p^{P H Y T O}[\text { PHYTO }]+p^{P O M_{\text {small }}\left[\text { POM }_{\text {small }}\right]}} \quad$ with $p^{X}=p^{\text {PHYTO }}$ or $p^{\text {POM }}$ small

Egestion of grazing

$E G E^{X}=\gamma_{Z} G R A Z^{X}$

Ammonium excretion

$\mathrm{EXC}_{\mathrm{NH}_{4}}=\varepsilon_{\mathrm{Z}} f(T)[\mathrm{ZOO}]$

Mortality loss

$M^{\text {MORT }}{ }^{Z O O}=m_{\text {ZOO }}[Z O O]$

Predation loss

$P R E D^{Z O O}=\omega_{Z}[Z O O]^{2}$

Limitation by temperature

$f(T)=e^{k_{T}^{z O O}(T)} \quad$ with $k_{T}^{Z 00}=\frac{\operatorname{Ln}\left(Q_{10}^{Z 0 O}\right)}{10}$

Implicit bacterial processes

Organic matter remineralisation

$R E M^{X}=r_{X}[X]$ with $X=\mathrm{POM}_{\text {small }}$ or $\mathrm{POM}_{\text {large }}$ or DON 
Nitrification

$N I T=r_{\mathrm{NH}_{4}}\left(T_{\mathrm{OPT}}\right)\left[\mathrm{NH}_{4}\right]\left(1-\frac{\operatorname{PAR}(\mathrm{z})}{\operatorname{PAR}(0)}\right) f(T)$

Limitation by temperature

$f(T)=e^{k_{N I T}\left(T-T_{\text {OPT }}\right)} \quad$ with $k_{\text {NIT }}=\frac{\operatorname{Ln}\left(Q_{10}^{N I T}\right)}{10}$

Appendix A.3. Definitions, symbols, units, values and references of the parameters used in the biogeochemical model

\begin{tabular}{|c|c|c|c|}
\hline Definition & Symbol & Unit & Value \\
\hline \multicolumn{4}{|l|}{ Phytoplankton } \\
\hline Maximum growth rate & $\mu^{\text {growth }}$ & $\mathrm{s}^{-1}$ & $1.7 \times 10^{-5(\mathrm{a})}$ \\
\hline Half-saturation constant for nitrate uptake & $k_{\mathrm{NO}_{3}}$ & $\mathrm{mmol} \mathrm{N} \mathrm{m}^{-3}$ & $0.3^{(\mathrm{b})}$ \\
\hline Half-saturation constant for ammonium uptake & $k_{\mathrm{NH}_{4}}$ & $\mathrm{mmol} \mathrm{N} \mathrm{m}^{-3}$ & $0.15^{(\mathrm{c})}$ \\
\hline Inhibition constant of nitrate uptake by ammonium & $k_{I}$ & $\mathrm{mmol} \mathrm{N} \mathrm{m}^{-3}$ & $8 \times 10^{-3(d)}$ \\
\hline Maximum inhibition rate of nitrate uptake by ammonium & $I_{M}$ & - & $0.82^{(\mathrm{d})}$ \\
\hline Photosynthetic coefficient of van't Hoff & $a_{T}$ & - & $1.07^{(\mathrm{e})}$ \\
\hline Photoinhibition parameter & $\beta$ & - & $0.01^{(\mathrm{e})}$ \\
\hline PAR for $f(P A R)=0.5$ & $K_{P A R}\left(T_{O P T}\right)$ & $\mathrm{W} \mathrm{m}^{-2}$ & $8.4^{(\mathrm{e})}$ \\
\hline Optimal photosynthesis temperature & $T_{O P T}$ & ${ }^{\circ} \mathrm{C}$ & $15.5^{(\mathrm{f})}$ \\
\hline Dissolved organic nitrogen excretion rate & $\gamma_{N O D}$ & - & $0.05^{(\mathrm{g})}$ \\
\hline Mortality rate & $m_{P H Y T O}$ & $\mathrm{~s}^{-1}$ & $9 \times 10^{-7(\mathrm{~h})}$ \\
\hline Aggregation rate & $a_{\text {PHYTO }}$ & $\mathrm{m}^{3} \mathrm{mmol} \mathrm{N}^{-1} \mathrm{~s}^{-1}$ & $1.15 \times 10^{-6(\mathrm{i})}$ \\
\hline Phytoplankton sedimentation rate & $w_{\text {PHYTO }}$ & $\mathrm{ms}^{-1}$ & $1.16 \times 10^{-5(\mathrm{f})}$ \\
\hline Fraction of $P O M_{\text {small }}$ to $P O M_{\text {pool }}$ & $\delta_{P O M}^{\text {PHYTO }}$ & - & $1.0^{(\mathrm{j})}$ \\
\hline \multicolumn{4}{|l|}{ Zooplankton } \\
\hline Maximum grazing rate & $g_{\text {MAX }}$ & $\mathrm{s}^{-1}$ & $1.5 \times 10^{-5(\mathrm{a})}$ \\
\hline Grazing preference for phytoplankton & $p^{P H Y T O}$ & - & $0.75^{(\mathrm{h})}$ \\
\hline Egestion fraction & $\gamma_{Z}$ & - & $0.30^{(\mathrm{k})}$ \\
\hline Natural mortality rate & $m_{\text {Zoo }}$ & $\mathrm{s}^{-1}$ & $5.8 \times 10^{-7(f)}$ \\
\hline Mortality rate by predation & $\omega_{Z}$ & $\mathrm{~m}^{3} \mathrm{mmol} \mathrm{N}^{-1} \mathrm{~s}^{-1}$ & $2.08 \times 10^{-6(i)}$ \\
\hline Ammonium excretion rate & $\omega_{Z}$ & $\mathrm{~s}^{-1}$ & $7.75 \times 10^{-7(f)}$ \\
\hline Half-saturation constant for grazing & $k_{Z}$ & $\mathrm{mmol} \mathrm{N} \mathrm{m}^{-3}$ & $1.10^{(\mathrm{h})}$ \\
\hline Parameter of the temperature function & $Q_{10}^{Z O O}$ & - & $1.50^{(1)}$ \\
\hline Fraction of $P O M_{\text {small }}$ to $P O M_{\text {pool }}$ & $\delta_{P O M}^{Z O O}$ & - & $0.85^{(\mathrm{j})}$ \\
\hline \multicolumn{4}{|l|}{ Particulate organic matter } \\
\hline$P O M_{\text {small }}$ remineralisation rate & $r_{P O M_{S M A L L}}$ & $\mathrm{~s}^{-1}$ & $1.16 \times 10^{-6(f)}$ \\
\hline$P O M_{\text {large }}$ remineralisation rate & $r_{P O M_{L A R G E}}$ & $\mathrm{~s}^{-1}$ & $9.26 \times 10^{-7(f)}$ \\
\hline$P O M_{\text {large }}$ sedimentation rate & $w_{P O M_{L A R G E}}$ & $\mathrm{~ms}^{-1}$ & $8.10 \times 10^{-4(f)}$ \\
\hline$P O M_{\text {small }}$ sedimentation rate & $w_{\text {POM }}$ SMALL & $\mathrm{ms}^{-1}$ & $8.10 \times 10^{-5(f)}$ \\
\hline \multicolumn{4}{|l|}{ Dissolved organic matter and ammonium } \\
\hline DON regeneration rate & $r_{D O N}$ & $\mathrm{~s}^{-1}$ & $8.30 \times 10^{-8(\mathrm{~m})}$ \\
\hline$Q_{10}$ constant for nitrification & $Q_{10}^{N I T}$ & - & $2.0^{(\mathrm{n})}$ \\
\hline Optimal nitrification temperature & $T_{O P T}$ & ${ }^{\circ} \mathrm{C}$ & $13.0^{(\mathrm{m})}$ \\
\hline Nitrification rate at $13^{\circ} \mathrm{C}$ & $r_{\mathrm{NH}_{4}}\left(T_{\mathrm{OPT}}\right)$ & $\mathrm{s}^{-1}$ & $5.8 \times 10^{-7(\mathrm{~m})}$ \\
\hline
\end{tabular}

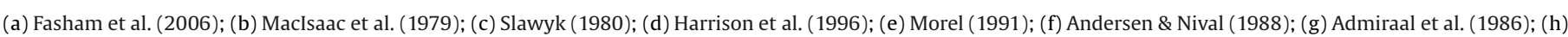
Fasham et al. (1990); (i) Doney et al. (1996); (j) Miquel et al. (1994); (k) Mauchline (1998); (l) Pondaven et al. (1999); (m) Diaz (2000); (n) Pinazo et al. (1996).

\section{References}

Admiraal, W., Peletier, H., Laane, R.W.P., 1986. Nitrogen metabolism of marine planktonic diatoms; excretion, assimilation and cellular pool of free amino acids in seven species with different cell size. Journal of Experimental and Marine Biology 98, 241-263.

Andersen, V., Nival, P., 1988. A pelagic ecosystem model simulating production and sedimentation of biogenic particles: role of salps and copepods. Marine Ecology Progress Series 44, 37-50.

Arakawa, A., Lamb, V.R., 1977. Computational design of the basic dynamical processes of the UCLA general circulation model. Methods in Computional Physics 17, 174-267.

Baklouti, M., Faure, V., Pawlowski, L., Sciandra, A., 2006. Investigation and sensitivity analysis of a mechanistic phytoplankton model implemented in a new modular numerical tool (Eco3M) dedicated to biogeochemical modelling. Progress in Oceanography 71 (1), 34-58.

Bouffard, J., Vignudelli, S., Herrmann, M., Lyard, F., Marsaleix, P., Ménard, Y., Cipollini, P., 2008. Comparison of ocean dynamics with a regional circulation model and improved altimetry in the North-western Mediterranean. Terrestrial, Atmospheric and Oceanic Sciences 19, 1-XXX.
Broche, P., Devenon, J.-L., Forget, P., de Maistre, J.C., Naudin, J.J., Cauwet, G., 1998. Experimental study of the Rhone plume. Part I: physics and dynamics. Oceanologica Acta 21 (6), 725-738.

Carmillet, V., Brankart, J.M., Brasseur, P., Drange, H., Evensen, G., Verron, J., 2001 Assimilation of ocean color data into an ecosystem model of the North Atlantic ocean. Ocean Modelling 3, 167-192.

Demirov, E., Pinardi, N., 2002. Simulation of the Mediterranean Sea circulation from 1979 to 1993. Part I: the interannual variability. Journal of Marine Systems 33-34 (C), 23-50.

Diaz, F., 2000. Evolution saisonnière de la production primaire et des processus d'assimilation-régénération de l'azote dans le Golfe du Lion. Estimation d'un bilan de carbone. Approche in situ et modélisation. Ph.D. Thesis, University de la Méditerranée, Marseille, France, unpublished.

Doney, S.C., Glover, D.M., Najjar, R.G., 1996. A new coupled, one-dimensional biological-physical model for the upper ocean: application to the JGOFS Bermuda Atlantic Time-Series study (BATS) site. Deep-Sea Research 43 (2-3) 591-624.

Eppley, R.W., Renger, E.H., Harrison, W.G., Cullen, J.J., 1979. Ammonium distribution in southern California coastal waters and its role in the growth of phytoplankton. Limnology and Oceanography 24, 494-509. 
Estournel, C., Broche, P., Marsaleix, P., Devenon, J.L., Auclair, F., Vehil, R., 2001. The Rhone River Plume in unsteady conditions: numerical and experimental results. Estuarine, Coastal and Shelf Science 53 (1), 25-38.

Estournel, C., Auclair, F., Lux, M., Nguyen, C., Marsaleix, P., 2007. Scale oriented embedded modeling of the North-western Mediterranean in the frame of MFSTEP. Ocean Science Discussions 4, 145-187.

Estournel, C., Kondrachoff, V., Marsaleix, P., Vehil, R., 1997. The plume of the Rhone: numerical simulation and remote sensing. Continental Shelf Research 17 (8), 899-924.

Fasham, M.J.R., Ducklow, H.W., McKelvie, S.M., 1990. A nitrogen-based model of plankton dynamics in the oceanic mixed layer. Journal of Marine Research 48 591-639.

Fasham, M.J.R, Flynn, K.J., Pondaven, P., Anderson, T.R., Boyd, P.W., 2006. Development of a robust marine ecosystem model to predict the role of iron in biogeochemical cycles: a comparison of results for iron-replete and ironlimited areas, and the SOIREE iron-enrichment experiment. Deep-sea Research 53, 333-366.

Feldman, G.C., McClain, C.R., 2007. Ocean Color Web, SeaWifs Reprocessing 5, NASA Goddard Space Flight Center. Kuring, N., Bailey, S. W. (Eds.), 〈http:// oceancolor.gsfc.nasa.gov/ $>$.

Friedrichs, M.A.M., 2001. Assimilation of JGOFS EqPac and SeaWiFS data into a marine ecosystem model of the central equatorial Pacific Ocean. Deep-sea Research II 49, 289-319.

Gohin, F., Druon, J.N., Lampert, L., 2002. A five channel chlorophyll concentration algorithm applied to SeaWiFS data processed by SeaDAS in coastal waters. International Journal of Remote Sensing 23 (8), 1639-1661.

Gohin, F. Loyer, S., Lunven, M., Labry, C., Froidefond, J.M., Delmas, D., Huret, M., Herbland, A., 2005. Satellite-derived parameters for biological modelling in coastal waters: Illustration over the eastern continental shelf of the Bay of Biscay. Remote Sensing of Environment 95 (1), 29-46.

Gregg, W.W., 2008. Assimilation of SeaWiFS ocean chlorophyll data into a threedimensional global ocean model. Journal of Marine Systems 69 (3-4), 205-225.

Haney, R.L., 1991. On the pressure gradient force over steep topography in sigma coordinate ocean models. Journal of Physical Oceanography 21, 610-619.

Harmon, R., Challenor, P., 1997. A Markov chain Monte Carlo method for estimation and assimilation into models. Ecological Modelling 101, 41-59.

Harrison, W.G., 1993. Nutrient recycling in production experiments. ICES Marine Science Symposia 197, 149-158.

Harrison, W.G., Harris, L.R., Irwin, B.D., 1996. The kinetics of nitrogen utilization in the oceanic mixed layer: nitrate and ammonium interactions at nanomolar concentrations. Limnology and Oceanography 41 (1), 16-32.

Huret, M., Gohin, F., Delmas, D., Lunven, M., Garçon, V., 2007. Use of SeaWiFS data for light availability and parameter estimation of a phytoplankton production model of the Bay of Biscay. Journal of Marine Systems 65 (1-4), 509-531.

Ide, K., Bennet, A.F., Courtier, P., Ghil, M., Lorenc, A.C., 1997. Unified notation for data assimilation: operational, sequential and variational. Journal of Meteorological Society of Japan 75 (1B), 181-189.

Leitaõ, P., Coelho, H., Santos, A., Neves, R., 2005. Modeling the main features of the Algarve coastal circulation during July 2004: a downscalling approch. Journal of Atmospheric and Ocean Science 10, 421-462.

Lenartz, F., Raick, C., Soetaert, K., Gregoire, M., 2007. Application of an Ensemble Kalman filter to a 1-D coupled hydrodynamic-ecosystem model of the Ligurian Sea. Journal of Marine Systems 68 (3-4), 561-583.

MacIsaac, J.J., Dugdale, R.C., Huntsman, S.A., Conway, H.L., 1979. The effect of sewage on uptake of inorganic nitrogen and carbon by natural populations of marine phytoplankton. Journal of Marine Research 37, 51-66.

Mauchline, J., 1998. The Biology of Calanoid Copepods. Academic Press, San Diego.

Marsaleix, P., Auclair, F., Estournel, C., 2006. Considerations on open boundary conditions for regional and coastal ocean models. Journal of Atmospheric and Oceanic Technology 23, 1604-1613.

Marsaleix, P., Auclair, F., Floor, J.W., Herrmann, M.J., Estournel, C., Pairaud, I., Ulses, $C .2008$. Energy conservation issues in sigma-coordinate free-surface ocean models. Ocean Modelling.

McIntyre, A.D., 1995. Human impact on the oceans: the 1990s and beyond. Marine Pollution Bulletin 31, 147-151.

Millot, C., 1990. The Gulf of Lions' hydrodynamics. Continental Shelf Research 10 (9-11), 885-894.

Minas, M., Minas, H.J., 1989. Primary production in the Gulf of Lions with considerations to the Rhone River input. Water Pollution Research Reports 13, 112-125.
Miquel, J.C., Fowler, S.W., La Rosa, J., Buat-Ménard, P., 1994. Dynamics of the downward flux of particles and carbon in the open northwestern Mediterranean Sea. Deep-Sea Research 41 (2), 243-261.

Moore, J.K., Doney, S.C., Lindsay, K., 2004. Upper ocean ecosystem dynamics and iron cycling in a global three-dimensional model. Global Biogeochemical Cycles 18 (4), GB4028.

Morel, A., 1991. Light and marine photosynthesis: a spectral model with geochemical and climatological implications. Progress in Oceanography 26, 263-306.

Naudin, J.J., Cauwet, G., Fajon, C., Oriol, L., Terzicn, S., Devenon, J.-L., Brochen, B., 2001. Effect of mixing on microbial communities in the Rhone River plume. Journal of Marine Systems 28 (3-4), 203-227.

Ouillon, S., Petrenko, A., 2002. Above-water measurements of reflectance and chlorophyll-a algorithms in the Gulf of Lions, NW Mediterranean Sea. Optics Express 13, 2531-2548.

Pham, D., Verron, J., Roubaud, M.C., 1998. A singular evolutive extended Kalman filter for data assimilation in oceanography. Journal of Marine Systems 16 (3-4), 323-340.

Pinazo, C., Marsaleix, P., Millet, B., Estournel, C., Véhil, R., 1996. Spatial and temporal variability of phytoplankton biomass in upwelling areas of the northwestern Mediterranean: a coupled physical and biogeochemical modeling approach. Journal of Marine Systems 7, 161-191.

Pondaven, P., Ruiz-Pino, D., Druon, J.N., Fravalo, C., Tréguer, P., 1999. Factors controlling silicon and nitrogen biogeochemical cycles in high nutrient, low chlorophyll systems (the Southern Ocean and the North Pacific): comparison with a mesotrophic system (the North Atlantic). Deep-Sea Research 46, 1923-1968.

Raick, C., Alvera-Azcarate, A., Barth, A., Brankart, J.M., Soetaert, K., Gregoire, M., 2007. Application of a SEEK filter to a 1D biogeochemical model of the Ligurian Sea: twin experiments and real in-situ data assimilation. Journal of Marine Systems 65 (1-4), 561-583.

Schartau, M., Oschlies, A., Willebrand, J., 2001. Parameter estimates of a zerodimensional ecosystem model applying the adjoint method. Deep-sea Research II 48, 1796-1800.

Slawyk, G., 1980. Absorption des composés azotés par le phytoplancton marin: rôle dans la production primaire, relations avec la photosynthèse et les variables du milieu extra-et intracellulaire. Ph.D. thesis, Univ. Aix-Marseille II, Marseille, France, unpublished.

Spitz, Y.H., Moisan, J.R., Abbott, M.R., 2001. Configuring an ecosystem model using data from the Bermuda Atlantic Time Series (BATS). Deep-Sea Research II 48 , 1733-1768.

Testut, C.E., Brasseur, P., Brankart, J.M., Verron, J., 2003. Assimilation of sea-surface temperature and altimetric observations during 1992-1993 into an eddy permitting primitive equation model of the North Atlantic Ocean. Journal of Marine Systems 40-41, 291-316.

Tett, P., Gilpin, L., Svendsen, H., Erlandsson, C.P., Larsson, U., Kratzer, S., Fouilland, E., Janzen, C., Lee, J.-Y., Grenz, C., 2003. Eutrophication and some European waters of restricted exchange. Continental Shelf Research 23 (17-19), 1635-1671.

Tett, P., Gowen, R., Mills, D., Fernandes, T., Gilpin, L., Huxham, M., Kennigton, K., Read, P., Service, M., Wilkinson, M., Malcolm, S., 2007. Defining and detecting undesirable disturbance in the context of marine eutrophication. Marine Pollution Bulletin 55 (1), 282-297.

Triantafyllou, G., Hoteit, I., Petihakis, G., 2003. A singular evolutive interpolated Kalman filter for efficient data assimilation in a 3-D complex physicalbiogeochemical model of the Cretan Sea. Journal of Marine Systems 40-41, 213-231.

Ulses, C., Grenz, C., Marsaleix, P., Schaaff, E., Estournel, C., Meule, S., Pinazo, C., 2005. Circulation in a semi-enclosed bay under influence of strong freshwater input. Journal of Marine Systems 56 (1-2), 113-132.

Ulses, C., Estournel, C., Bonnin, J., Durrieu de Madron, X., Marsaleix, P., 2008. Impact of storms and dense water cascading on shelf-slope exchanges in the Gulf of Lion (NW Mediterranean). Journal of Geophysical Research 113 (C02010).

Van den Meersche, K., Middelburg, J.J., Soetaert, K., van Rijswijk, P., Boschker, H.T.S., Heip, C.H.R., 2004. Carbon-nitrogen coupling and algal-bacterial interactions during an experimental bloom: modeling a $13 \mathrm{C}$ tracer experiment. Limnology and Oceanography 49 (3), 862-878.

Verron, J., Gourdeau, L., Pham, D.T., Murtugudde, R., Busalacchi, A.J., 1999. An extended Kalman filter to assimilate satellite altimeter data into a non-linear numerical model of the tropical Pacific: methods and validation. Journal of Geophysical Research 1004 (C3), 5441-5458. 